AHMAR METAKARYA: JURNAL PENGABDIAN MASYARAKAT

Available online at: http://journal.ahmareduc.or.id/index.php/AMJPM Vol.1, No.2, Februari 2022, Halaman 102-106.

p-ISSN 2807-3797 e-ISSN 2807-3576

\title{
Sosialisasi, Edukasi Penerapan Protokol Kesehatan Pada Masa New Normal Di Desa Ruyung Tahun 2021
}

\author{
Saudah \\ Akademi Kebidanan Saleha, Banda Aceh, Indonesia \\ *E-mail:saudah.stafsaleha@gmail.com
}

Received: 29 Januari 2022

Accepted: 27 Februari 2022

Published: 28 Februari 2022

\begin{abstract}
Corona virus as a virus that will cause the common cold to more severe diseases such as Middle East Respiratory Syndrome (MERS-CoV) and Severe Acute Respiratory Syndrome (SARSCoV). When the Covid19 pandemic occurred, Indonesian people who had various social characteristics, ranging from age group, education level, economic status, were exposed to the internet/mass media, social environment, culture, ethnicity, and others and had different understandings and attitudes. various aspects of the Covid-19 pandemic, not all members of the public comply with health protocols. The habit of washing hands using water alone cannot protect every individual from bacteria and viruses found on their hands. Especially if you don't wash your hands under running water. Moreover, the habit of using and sharing hand washing containers is the same as sharing germs with each other and still allowing germs to stick to hands. This habit must be abandoned and changed to a better one with standard procedures for washing hands with soap. Wearing a mask also protects the lungs from pollution, prevents disease transmission and prevents the face from being exposed to excessive sunlight. While maintaining distance is an action to prevent infectious diseases, by keeping a distance between one person and another can prevent the transmission of covid-19. The purpose of this community service is to provide education to the public about health protocols. The method in implementing this service goes through several stages, namely first, by reviewing the location to be addressed and then conducting discussions with the management. understanding of health protocols after being given education obtained respondents who already understood as many as $68 \%$ and respondents who did not understand decreased to $32 \%$, it was concluded that there was an increase in understanding of health protocols in the new normal period. It is hoped that the community will continue to maintain health protocols to break the chain of the spread of COVID-19.
\end{abstract}

Keywords: Socialization and Examination, Health Protocol and Blood Pressure Examination, New Normal Period.

\begin{abstract}
Abstrak
Virus corona sebagai virus yang akan mengakibatkan flu biasa hingga penyakit yang lebih parah seperti sindrom pernapasan timur tengah (MERS-CoV) dan Sindrom pernafasan akut parah (SARSCoV). Ketika pandemi Covid-19 terjadi, masyarakat Indonesia yang memiliki karakteristik sosial yang beragam, mulai dari kelompok usia, tingkat pendidikan, status ekonomi, terpapar internet/media massa, lingkungan sosial, budaya, suku, dan lain-lain dan memiliki pemahaman dan sikap yang beragam terhadap pandemi Covid-19 tidak semua anggota masyarakat patuh pada protokol kesehatan. Kebiasaan dalam cuci tangan menggunakan air saja tidak dapat melindungi setiap individu dari bakteri dan virus yang terdapat di tangan. Terlebih jika mencuci tangan tidak di bawah air mengalir. Apalagi kebiasaan menggunakan dan berbagi wadah cuci tangan hal itu sama saja saling berbagi kuman dan tetap membiarkan kuman menempel pada tangan. Kebiasaan itu harus ditinggalkan dan dirubah menjadi yang lebih baik dengan standar prosedur melakukan cuci tangan menggunakan sabun. Memakai masker juga menjaga paru-paru terhindar dari polusi, mencegah penularan penyakit dan mencegah wajah terpapar dari sinar matahari berlebihan.
\end{abstract}


Sedangkan menjaga jarak merupakan tindakan untuk mencegah penyakit menular, dengan menjaga jarak anatara satu orang dengan orang lain dapat menceegah penularan covid-19. Tujuan dari pengabdian masyarakat ini untuk memberikan edukasi pada masyarakat tentang protokol kesehatan. Metode dalam pelaksanaan pengabdian ini melalui beberapa tahapan yaitu pertama, dengan meninjau lokasi yang akan dituju dan selajutnya melakukan diskusi dengan pengurus. pemahaman tentang protokol kesehatan sesudah diberikan edukasi didapatkan responden yang sudah paham sebanyak $68 \%$ dan responden yang belum paham menurun menjadi $32 \%$ maka disimpulkan adanya peningkatan pemahaman tentang protokol kesehaan di masa new normal. Diharapkan kepada masyarakat agar menjaga protokol kesehatan secara terus menerus guna memutus mata rantai penyebaran covid-19.

Kata Kunci: Sosialisasi, Protokol Kesehatan, Masa New Normal.

\section{A. PENDAHULUAN}

Dalam upaya meningkatkan derajat kesehatan dan penyelenggaraan pembangunan kesehatan, terdapat berberapa tantangan yang dihadapi. Tantangan dalam upaya kesehatan terutama mengenai kesenjangan kualitas kesehatan dan akses terhadap pelayanan masyarakat yang bermutu antar wilayah, gender, dan antar kelompok tingkat sosial ekonomi dan belum optimalnya alokasi pembiayaan kesehatan masyarakat. Virus corona sebagai virus yang akan mengakibatkan flu biasa hingga penyakit yang lebih parah seperti sindrom pernapasan timur tengah (MERS-CoV) dan Sindrom penafasan akut parah (SARSCoV). Lalu ada dugaan bahwa virus corona awalnya ditularkan dari hewan ke manusia dan kemudian diketahui bahwa virus corona juga bisa menular dari manusia ke manusia..Awal mula penularannya berasal dari kota Wuhan yang merupakan salah satu dari Provinsi di negara cina dan hebatnya secara cepat menjangkiti hampir seluruh negara-negara didunia sehingga WHO menyatakan bahwa dunia memasuki fase darurat secara global akibat pandemik yang berlangsung ini (Wardhani, et. al., 2020).

Enam kriteria new normal, yaitu (1) penularan Covid-19 sudah terkendali; (2) sistem kesehatan dapat mendeteksi, menguji, mengisolasi, melacak kasus dan mengkarantina pasien Covid-19; (3) risiko penularan dapat dikurangi terutama di tempat dengan kerentanan tinggi seperti panti jompo, fasilitas kesehatan mental dan tempat keramaian; (4) upaya pencegahan di lingkungan kerja seperti jaga jarak fisik, fasilitas cuci tangan, serta etika saat bersin dan batuk; (5) pencegahan kasus Covid-19 dari luar negeri; serta (6) imbauan masyarakat untuk berpartisipasi dalam masa transisi new normal (WHO, 2020).

Perilaku Hidup Bersih dan Sehat (PHBS) masyarakat sebelum pandemi Covid-19 masih rendah. PHBS terdiri dari kebiasaan cuci tangan memakai sabun, konsumsi makanan sehat, aktivitas fisik, istirahat yang cukup, air bersih, sanitasi layak, tidak merokok, dan lain-lain. Data Kementerian Kesehatan Tahun 2019 menunjukkan bahwa sebesar 55\% rumah tangga di Indonesia mempraktikkan PHBS dan 69,27\% rumah tangga memili ki akses terhadap sanitasi layak. Ketika pandemi Covid-19 terjadi, masyarakat Indonesia yang memiliki karakteristik sosial yang beragam, mulai dari kelompok usia, tingkat pendidikan, status ekonomi, terpapar internet/media massa, lingkungan sosial, budaya, suku, dan lain-lain, memiliki pemahaman dan sikap yang beragam terhadap pandemi Covid-19. Pemahaman dan sikap yang terbentuk dapat memengaruhi tindakan/perilaku masyarakat. Tidak semua anggota masyarakat patuh pada protokol kesehatan (Ningrum, et. al., 2021).

Memberikan edukasi kepada masyarakat sangat dapat mencegah penularan covid-19. Meskipun banyak faktor yang mempengaruhi perilaku yang berhubungan dengan kesehatan, kesadaran akan risiko untuk membuat perubahan perilaku masyarakat adalah unsur utama untuk meningkatkan kesehatan individu dan status kesehatan masyarakat agar terhindar dari covid-19 (Sampurno, et. al., 2020)

Pentingnya komunikasi yang efektif karena bisa membuat orang yang diberikan edukasi mengerti dengan informasi yang disampaikan. Komunikasi pada dasarnya adalah sebuah aktivitas antara dua orang atau lebih untuk saling berbagi informasi atau saling tukar pikiran memberikan informasi atau pesan yang ditujukan kepada sang penerima pesan atau informasi. Prinsip pencegahan dan strategi pengendalian secara umum saat ini masih belum ada vaksin 
untuk mencegah infeksi covid-19. Cara terbaik untuk mencegah infeksi adalah dengan menghindari terpapar virus penyebab. Lakukan tindakan-tindakan pencegahan penularan dalam praktik kehidupan sehari-hari (Albert, et. al., 2016).

Layanan Pengabdian Masyarakat merupakan cara untuk meningkatkan pengetahuan masyarakat dalam menerapkan protokol kesehatan. Oleh karena itu, kegiatan pengabdian kepada masyarakat dilakukan sebagai tindakan pro-aktif untuk mencegah penyebaran covid-19, seperti menggunakan masker, menerapkan physical distancing, penggunaan alat pelindung diri oleh tim medis sebelum dimulainya kegiatan. Berdasarkan alasan tersebut, maka tujuan dari dilaksanakannya pengabdian masyarakat ini adalah untuk melakukan deteksi dini untuk mencegah penyebaran covid- sebagai bentuk pengabdian kepada masyarakat.

\section{B. METODE DAN PELAKSANAAN}

Pelaksanaan dan metode pengabdian masyarakat ini melalui beberapa tahapan yaitu pertama, dengan meninjau lokasi yang akan dituju, kedua melakukan diskusi dengan pengurus wilayah dan geucik desa Ruyung, ketiga pelaksanaan kegiatan lakukan pada senin, 15 November 2021 bertempat di Desa Ruyung selama 1 hari. Kegiatan ini berjalan lancar dengan di hadiri oleh 56 orang.

\section{HASIL DAN PEMBAHASAN}

Tabel 1. Disribusi frekuensi pemahaman tentang protokol kesehatan sebelum dilakukan sosialisasi dan edukasi.

\begin{tabular}{lrr}
\multicolumn{1}{c}{ Kaegori } & Frekuensi & Persentase(\%) \\
\hline Paham & 17 & 30,3 \\
Belum Paham & 39 & 69,7 \\
\hline Jumlah & 56 & 100 \\
\hline
\end{tabular}

Tabel 1 terlihat pemahaman masyarakat sebelum intervensi tentang protokol kesehatan yang belum paham yaitu sebanyak 32 orang (\%)

Tabel 2. Disribusi frekuensi pemahaman tentang protokol kesehatan setelah dilakukan sosialisasi dan edukasi.

\begin{tabular}{lrrr}
\hline & Kaegori & Frekuensi & Persentase(\%) \\
\hline Paham & 38 & 68 \\
Belum Paham & 18 & 32 \\
\hline Jumlah & 56 & 100 \\
\hline
\end{tabular}

Tabel 2 terlihat pemahaman masyarakat setelah intervensi tentang protokol kesehatan yang belum paham yaitu sebanyak 16 orang (\%).

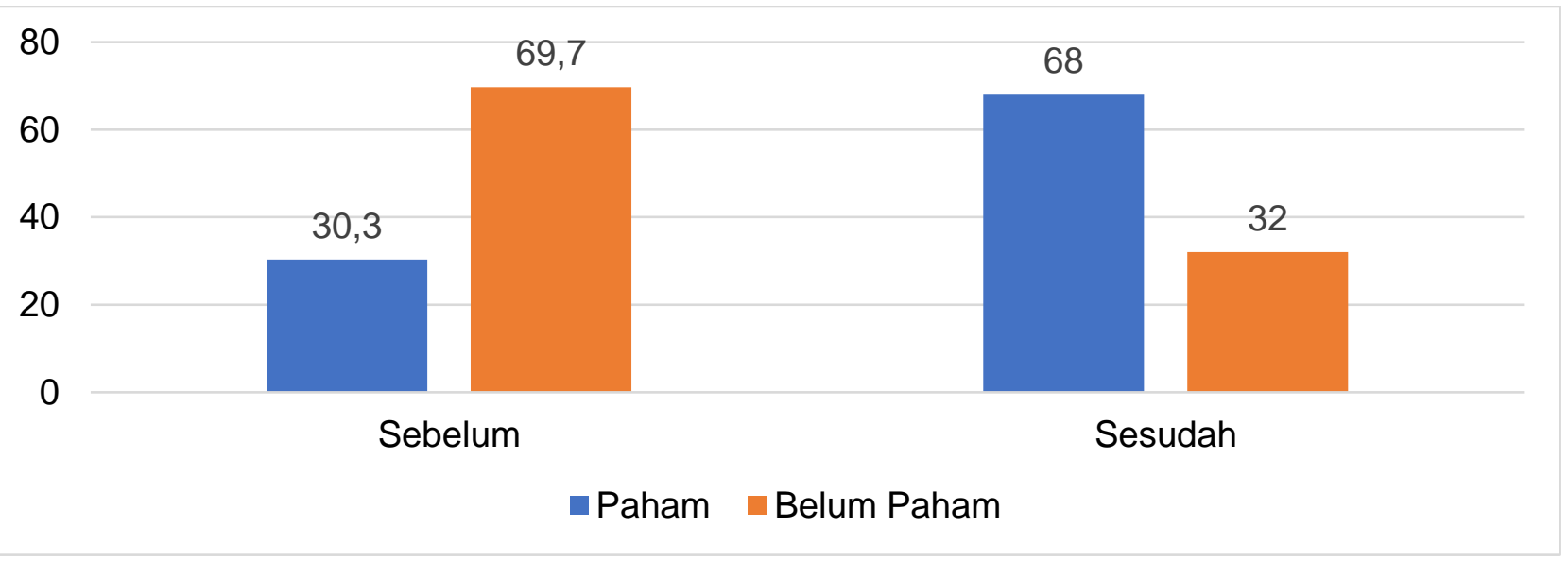

Diagram 1 terlihat perbandingan yang signifikan sebelum dan sesudah diberikan edukasi tentang protokol kesehatan. sebelum di lakukannya intervensi terlihat pemahaman responden hanya 30,3\% dan setelah diberikan intervensi naik sebesar $68 \%$ 
Hasil dari tabel 1 edukasi pemahaman tentang protokol kesehatan sebelum diberikan edukasi yang ikuti 56 responden didapatkan responden yang belum paham sebanyak $69,7 \%$ dan responden yang sudah paham sebanyak $30,3 \%$. Sebagian besar responden masih belum paham tentang protokol kesehatan.

Hasil dari tabel 2 edukasi pemahaman tentang protokol kesehatan sesudah diberikan edukasi didapatkan responden yang sudah paham sebanyak $68 \%$ dan responden yang belum paham menurun menjadi $32 \%$. Sebagian besar responden sudah paham tentang protokol kesehatan setelah diberikan edukasi.

Hasil penelitian ini sejalan dengan penelitian sebelumnya yang dilakukan oleh Mujburrahman (2020), dengan hasil penelitian menunjukan bahwa pengetahuan responden tentang pencegahan covid-19 sebagian besar sama berkategori baik yaitu sebanyak (82,7\%), Penelitian lainnya juga yang sejalan yaitu yang dilakukan oleh Syakurah (2020), dengan hasil ada sebanyak $(76,9 \%)$ atau sebagian besar responden memiliki pengetahuan yang baik terkait usaha pencegahan Coronavirus Disease (COVID-19) di Indonesia.

Covid-19 atau disebut juga dengan Corona Virus adalah kelompok virus yang bisa menyebabkan penyakit, baik itu pada manusia maupun pada hewan, pada manusia bisa menyebabkan infeksi saluran pernafasan mulai dari flu biasa sampai penyakit yang serius seperti Middle East Respiratory Syndroma (MERS) dan syndroma pernafasan akut berat/ Severe Acute Respiratory Syndroma (SARS). Covid-19 adalah penyakit menular disebabkan oleh corona virus yang baru ditemukan di Wuhan Tiongkok pada bulan Desember 2019. Komisi Kesehatan Nasional (NHC) Republik Rakyat Tiongkok kemudian mengumumkan hal itu dengan Corona Virus Novel, yang sekarang bernama Covid-19. Covid-19 inilah yang menjadi pandemik yang terjadi di banyak negara di seluruh dunia pada saat sekarang ini (Ridlo, 2020).

Edukasi pemahaman masyarakat terhadap Protokol kesehatan ini sangat diperlukan. Tanda dan gejala umum infeksi Covid-19 antara lain gejala gangguan pernafasan akut seperti demam, batuk dan sesak napas. Masa inkubasi rata-rata 5-6 hari dengan masa inkubasi terpanjang 14 hari (Rohita, 2020).

Kebiasaan dalam cuci tangan menggunakan air saja tidak dapat melindungi setiap individu dari bakteri dan virus yang terdapat di tangan. Terlebih jika mencuci tangan tidak di bawah air mengalir. Apalagi kebiasaan menggunakan dan berbagi wadah cuci tangan hal itu sama saja saling berbagi kuman dan tetap membiarkan kuman menempel pada tangan. Kebiasaan itu harus ditinggalkan dan dirubah menjadi yang lebih baik dengan standar prosedur melakukan cuci tangan menggunakan sabun. Memakai masker juga menjaga paru-paru terhindar dari polusi, mencegah penularan penyakit dan mencegah wajah terpapar dari sinar matahari berlebihan. Sedangkan menjaga jarak merupakan tindakan untuk mencegah penyakit menular, dengan menjaga jarak anatara satu orang dengan orang lain dapat menceegah penularan covid-19. (Kementerian Kesehatan Republik Indonesia, 2020).

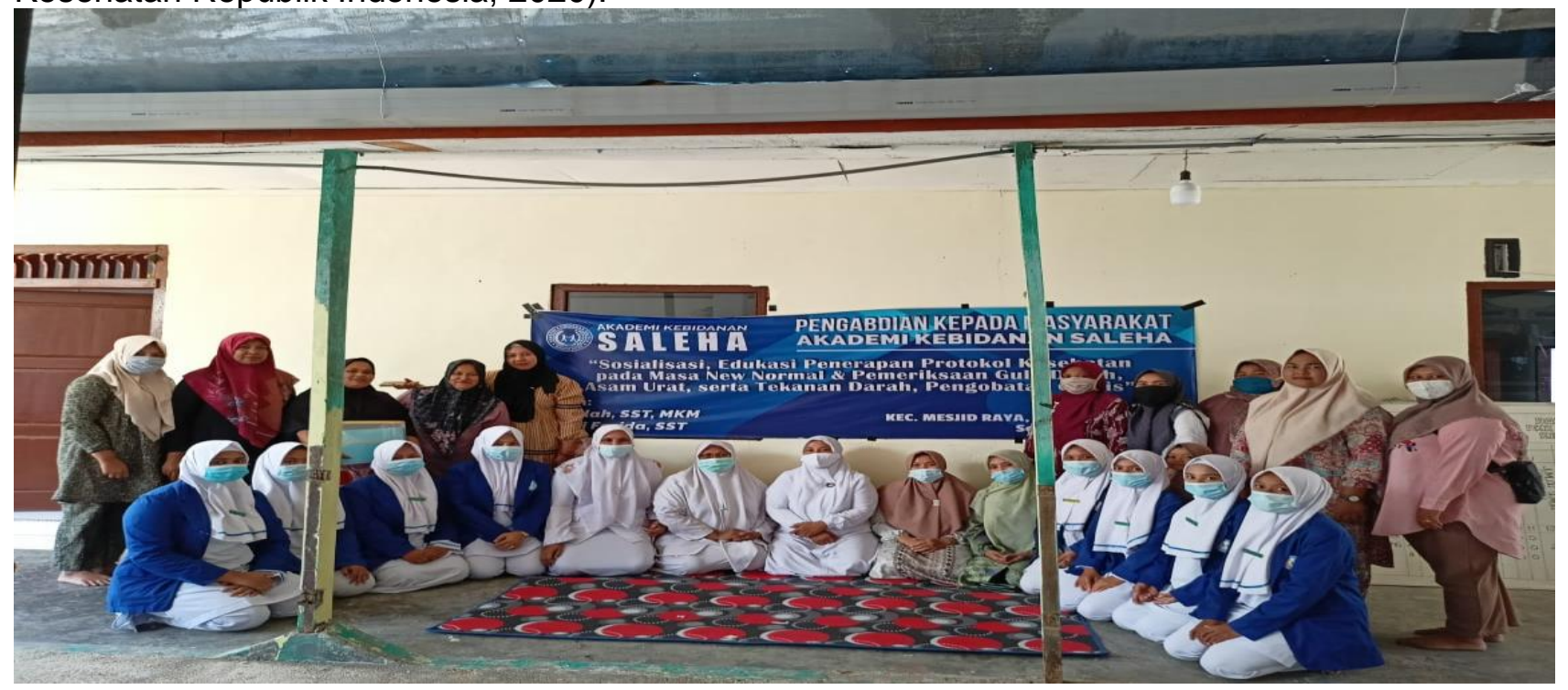



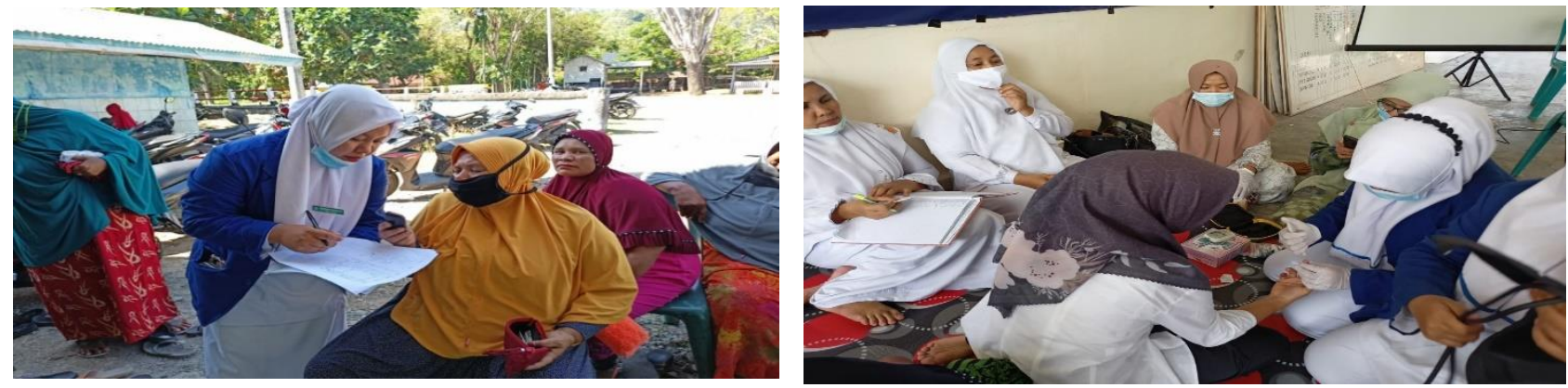

Gambar 1. Pelaksanaan Penyuluhan

\section{KESIMPULAN}

Berdasarkan hasil pengabdian masyarakat yang dilakukan dapat disimpulkan bahwa adanya peningkatan pemahaman tentang protokol kesehaan di masa new normal. Pemahaman tentang protokol kesehaan sesudah diberikan sosialisasi dan edukasi didapatkan sudah paham sebanyak $68 \%$.

\section{UCAPAN TERIMA KASIH}

Terimakasih kepada yayasan kutaraja, direkur beserta staff akbid saleha yang telah memberikan izin dan seluruh perangka desa dan masyarakat desa Ruyung yang membantu dalam pengabdian masyarakat ini.

\section{DAFTAR PUSTAKA}

Alber, J. M., Paige, S., Stellefson, M., \& Bernhardt, J. M. (2016). Social media Self-efficacy of Health Education specialists: training and organizational development implications. Health Promotion Practice, 17(6), 915-921

Kementerian Kesehatan, R. I. (2020). Panduan Pencegahan Penularan COVID-19 di Tempat dan Fasilitas Umum. Jakarta: Kementerian Kesehatan Republik Indonesia.

Mujiburrahman, Riyadi, M.E, Ningsih, M.U. (2020). Pengetahuan Berhubungan dengan Peningkatan Perilaku Pencegahan Covid-19 di Masyarakat. Jurnal Keperawatan Terpadu (Integrated Nursing Journal) 2 (2), 130-140.

Ningrum, S., Sulistyorini, L., \& Septiyono, E. A. (2021). Explorasi Perilaku Mencuci Tangan Anak Usia Sekolah Dalam Pencegahan Infkesi Covid-19 Di Banyuwangi, Jawa Timur. Jurnal IImu Keperawatan dan Kebidanan, 12(2), 200-207.

Ridlo, I. A. (2020). Pandemi Covid-19 dan tantangan kebijakan kesehatan mental di Indonesia. INSAN Jurnal Psikologi Dan Kesehatan Mental, 5(2), 162-171.

Rohita, R. (2020). Pengenalan Covid-19 pada anak usia prasekolah: analisis pada pelaksanaan peran orang tua di rumah. Jurnal Obsesi: Jurnal Pendidikan Anak Usia Dini, 5(1), 315-326.

Sampurno, M. B. T., Kusumandyoko, T. C., \& Islam, M. A. (2020). Budaya media sosial, edukasi masyarakat, dan pandemi COVID-19. SALAM: Jurnal Sosial Dan Budaya Syar I, 7(5), 52954.

Syakurah, R., \& Moudy, J. (2020). Pengetahuan terkait Usaha Pencegahan Coronavirus Disease (COVID-19) di Indonesia. HIGEIA (Journal of Public Health Research and Development, 4(3), 333-346.

Wardhani, D. K., Susilorini, M. R., Angghita, L. J., \& Ismail, A. (2020). Edukasi Pencegahan Penularan COVID-19 Pada Anak Usia Dini Melalui Media Pembelajaran Audio Visual. Jurnal Abdidas, 1(3), 131-136.

World Health Organization. (2020). Critical preparedness, readiness and response actions for COVID 19: interim guidance, 22 March 2020. Retrieved from https://www.who.int/publications/i/item/criticalpreparedness-readiness-and-responseactions-for-covid-19 